\title{
The effect of realistic mathematics education on student's mathematical communication ability
}

\author{
Trisnawati $^{{ }^{a^{*}}, \text { Rani Pratiwi }^{\mathrm{b}}, \text { Winia Waziana }}{ }^{\mathrm{c}}$ \\ a,b,c STMIK Pringsewu, Lampung, Indonesia \\ *Corresponding author: trisnawatistmikpsw@gmail.com
}

\section{ARTICLE HISTORY}

Received March 11, 2018

Revised April 20, 2018

Accepted May 5, 2018

\section{KEYWORDS}

Ralistics Mathematics Education Mathematical Communication

\begin{abstract}
This study aims to obtain a description of the application of Realistic Mathematic Education (RME) that can improve students' mathematical communication ability. The type of research used is a classroom action research that refers to the design of Kemmis and Mc.Taggart research they are planning, action, observation, and reflection. The results showed that Implementation of mathematics learning with Realistic Mathematics Education (RME) approach that can improve mathematical communication ability is a mathematics learning that has been done in accordance with RME characteristics, That is: use of real context (teacher presents a contextual problem and ask the student to understand the given problem). use of mathematical models (the students modeling by using props to solve problem), use of student production and construction in learning (the teacher gives opportunity to all students to solve the problem, and invite students to deliver the answer), existence of interaction (interaction occurs between teacher and students, and between student one with another), and the existence of integration (combines one unit of mathematics with other units also have integrated with other scientific fields).
\end{abstract}

This is an open access article under the CC-BY-SA license.

\section{INTRODUCTION}

Mathematics is not only a science, but also as a basic logic of reasoning and quantitative solutions used in other sciences. This means that mathematics plays an important role in the development of science and technology so that early mastery of mathematics requires students to master and create the technology of the future. Therefore, mathematics should be taught in the learning process in schools to equip students in order to develop the ability to use the language of mathematics in communicating ideas or ideas. according to Johnson and Rising (1972) cited by Erman Suherman's pattern of thinking, organizing patterns, logical proofs, mathematics is a language that uses precisely defined, clear, and accurate terms, its representation with solid and concise symbols, symbols of ideas rather than sounds. Mathematics studied in schools is mathematics whose material is chosen to be easily converted to their students' lives.

In mathematics learning, teacher communication with students and students with students is very important to achieve learning objectives. The process of communication in learning in the classroom occurs when students are responsive, active inquiring and responding to problems that exist, and able to pour both the problems either orally or in writing. When the communication process takes place, there are problems on a small scale and large scale. On a small scale, the problem that arises is the use of the right symbol, is on a large scale is the preparation of arguments against a statement logically. Both of these issues are the abilities that must be mastered so that the learning of mathematics becomes more meaningful. Meaningful learning is learning that allows students to build their own understanding of mathematical concepts and integrate them with existing knowledge (Richard E. Mayer, 1999: 6-7). While the ability in large scale and small scale is known as the ability of mathematical communication (Gerald Folland, 2001).

Mathematics learning in schools is also a communication process, namely the process of delivering messages in the form of material from the source of teachers or books to the recipient is students through a channel or a particular media. The process of communication in learning mathematics is said to be good if students are able to construct the knowledge gained. The students' mathematical communication skills are important to develop as they include the ability to communicate conceptual understanding, reasoning, and problem solving as the objectives of mathematics learning. Improvement of students' mathematical communication ability and significant learning achievement can be done by making changes in learning. In this case, it is necessary to design a learning that familiarizes students to construct their own knowledge, so that students better understand the concepts taught and able to communicate their thoughts with teachers, friends and the material itself. One way that can be done to improve students' mathematical communication skills is by implementing relevant learning approaches to be applied by teachers. Approach to learning that should be applied is a learning approach that provides opportunities for students to construct their own knowledge so that students are easier to understand the concepts taught and communicate ideas in 
the form of oral and written.

Currently the curriculum applied in Indonesia is The curriculum 2013 (K-13). The curriculum 2013 embraces the basic view that knowledge cannot be simply transferred from teacher to learner. Learners are subjects who have the ability to actively seek, process, construct, and use knowledge. For that learning should be related to the opportunities given to learners to construct knowledge in the cognitive process. Based on the Minister of Education and Culture of the Republic of Indonesia of 2013 No. $81 \mathrm{~A}$ on curriculum implementation, in learning the learner should construct knowledge for himself. For learners, the knowledge they possess is dynamic, evolving from simple to complex, from the scope of itself and beyond to a wider scope, and from the concrete to the abstract. However, there are still high school Mathematics teachers who do not relate the material delivered with daily life in the implementation of learning, and still many students who study the material without knowing the benefits or applications in everyday life. The stage of development of high school students is a transitional state from the concrete to the formal stage. a time when students have great curiosity and students can imagine or change everyday problems into a mathematical model. High school mathematics teachers need to understand the characteristics of mathematics subjects that are related to the characteristics of mathematical material, the objectives of the mathematics courses to be achieved and their implications in the management of mathematics learning. It is intended that the content of learning is planned and implemented does not deviate from the objectives of the subjects to be achieved and student learning outcomes can be achieved optimally.

One alternative attempt to support this is by applying the Realistic Mathematics Education (RME) learning approach. The selection of RME approach is reinforced by previous research conducted by Rian Hidayat in 2015 entitled "The Efect of Realistic Mathematics Education (RME) on Students' Conceptual Undestanding of Linear Progamming. The result of the research is The Implications of RME were useful for educators to help their students to understand concept of mathematics trough open and contextual questions so that the students though trough the mathematics, not worked in the mathematics. This is also in line with the result of research conducted by Anderson L.Palinusa, that is Achievement of students' critical mathematical thinking and quality character who were treated by Realistic Mathematics Education (RME) is better than conventional mathematics Education.

Historically, RME is a mathematical learning approach developed in the Netherlands some 47 years ago by the Freudenthal Institute (Gravemeijer, 1994). Fundamental changes are more focused on substituting mechanical learning mathematics to be realistic (Streefland, 1991). RME is much characterized by Freudenthal's view of mathematics. There are two important views according to Freudenthal that mathematics is connected with reality and mathematics is seen as human activity (Freudenthal, 1991). In connection with the two views above Gravemeijer (1994), it is said that mathematics should be cultivated near student life, must be linked to everyday life, and if it is real for the students. Students should be given free opportunities to learn to do mathematical or mathematical activities. In Indonesia, RME is called Realistic Mathematics Learning (PMR) or Realistic Learning Mathematics Indonesia (PMRI) (Hadi, 2005; Sembiring, 2001).
The principles and characteristics of RME mentioned above are in line with the Ministerial Regulation of the Minister of Education and Culture of the Republic of Indonesia of 2013 No. $81 \mathrm{~A}$ on the implementation of the curriculum which states that "To achieve the quality that has been designed in the curriculum document, learning activities need to use principles that: (1) (4) value, ethics, aesthetics, logic, and kinesthetic, and (5) provide a diverse learning experience through the application of various strategies and methods fun, contextual, effective, efficient, and meaningful learning ".

\section{METHOD}

The type of research used is a classroom action research that refers to the design of Kemmis and Mc.Taggart research they are planning, action, observation, and reflection. At the characteristic stage of RME the use of real context is in the learning activities of mathematics begins and uses real problems and approaches students or are often found by the students daily. Activities at this stage are called horizontal stages, based on observations, after being given real and close problems with students or often encountered by students in everyday life, students individually or in groups using mathematical models, it can build and interact, as facilitators in assisting the activities student affairs This is seen in the lessons that have been implemented after the researchers tell the contextual problems some students want to write a mathematical model.

This study uses one vertical instrument that is model, the model in this case relates to the mathematical model developed by the students themselves. For example, in learning the combination material each student develops a model based on their initial knowledge. During the course of the research, students are actively building their own mathematical concepts by utilizing existing learning resources and existing learning environments. Students can also solve problems in each way and students can perform conception discovery activities guided by the researcher.

\section{RESULTS AND DISCUSSION}

Mathematics learning with the RME approach is a mathematical learning that relates mathematics to everyday life. In this lesson contextual problems are used as a starting point. From the contextual problems are then used to find the concepts in mathematics. Learning with the Realistic Mathematics Education (RME) approach, the teacher (as a researcher) no longer acts as a learning center in the classroom but acts as a facilitator. So the task of teachers in learning is to guide learning activities to the learning process of students ranging from realistic contextual problem solving, discussing problems, linking some of the content of the lesson that has to do with the material being studied, and improve. His work to find more complex mathematical concepts works well. Teacher interaction with students is closer to monitoring and guiding students who are experiencing difficulties so as to create a fun learning environment.

Based on observations, mathematics learning with RME approach in class XI IPS 1 SMA Muhammadiyah 5 Yogyakarta has been done in accordance with the learning steps with RME approach. In the observation sheets of the implementation of mathematics learning with the RME approach, there are five observed aspects, namely the use of real context, the use of the model (mathematization), the use of production and 
construction, interactivity, and integration. Observations can be seen in the following table.

Table 1. Percentage of observation results of implementation of learning with RME Approach

\begin{tabular}{|c|c|c|c|c|}
\hline & \multicolumn{2}{|c|}{ Meeting } & \multirow{2}{*}{ Average } & \multirow{2}{*}{ Criteria } \\
\hline & 1 & 2 & & \\
\hline Cycle I & $76,19 \%$ & $90,48 \%$ & $83,34 \%$ & Very Good \\
\hline Cycle II & $95,24 \%$ & $95,24 \%$ & $95,24 \%$ & Very Good \\
\hline
\end{tabular}

Implementation cycle 1 , it appears that students individually, in pairs or groups there are an interaction between one student with another student. They discussed each other in completing a task given by the researcher. In addition students also interact with researchers when students have difficulties, so that researchers help students to become more understanding. In cycle 2, given the reflection with the integration and the interaction. It can be seen that researchers associate with other mathematical material as well as other subjects when researchers or students conclude the material being taught. This study does not lead students to use a strategy to solve a problem, but students develop strategies according to their knowledge and experience. Although the final answer is the same, the process of obtaining answers may be different.

Based on pretest results, Cycle 1 and Cycle 2 tests show an improvement in every aspect of mathematical communication. There are three aspects of mathematical communication: the ability to provide a rationale for a statement, the ability to transform the form of description into a mathematical model, and the ability to describe mathematical ideas into relevant forms of description (Wihatma, U. 2004: 24). The following is a table showing the percentage of improvement in students' mathematical communication skills for every aspect of mathematical communication.

Table 2. Increasing the percentage of student scores based on aspects of mathematical communication

\begin{tabular}{llccc}
\hline No. & \multicolumn{1}{c}{$\begin{array}{c}\text { Aspects of } \\
\text { Mathematical } \\
\text { Communication }\end{array}$} & Pretest & $\begin{array}{c}\text { Cycle } \\
\text { Test 1 }\end{array}$ & $\begin{array}{c}\text { Cycle } \\
\text { Test 2 }\end{array}$ \\
\hline 1 & $\begin{array}{l}\text { Ability to provide a } \\
\text { rationale for a } \\
\text { statement. }\end{array}$ & $58,04 \%$ & $59,52 \%$ & $72,22 \%$ \\
\hline & $\begin{array}{l}\text { Ability to change the } \\
\text { shape of the } \\
\text { description into the } \\
\text { mathematical model. }\end{array}$ & $51,46 \%$ & $70,00 \%$ & $79,77 \%$ \\
\hline & $\begin{array}{l}\text { Ability to illustrate } \\
\text { mathematical ideas } \\
\text { into relevant forms of } \\
\text { description. }\end{array}$ & $53,32 \%$ & $69,64 \%$ & $80,00 \%$ \\
$\quad$ Average & $54,27 \%$ & $66,39 \%$ & $77,33 \%$ \\
\hline
\end{tabular}

An increase in the percentage of values for each aspect of mathematical communication will be much more apparent on the bar graph that the researchers present below.

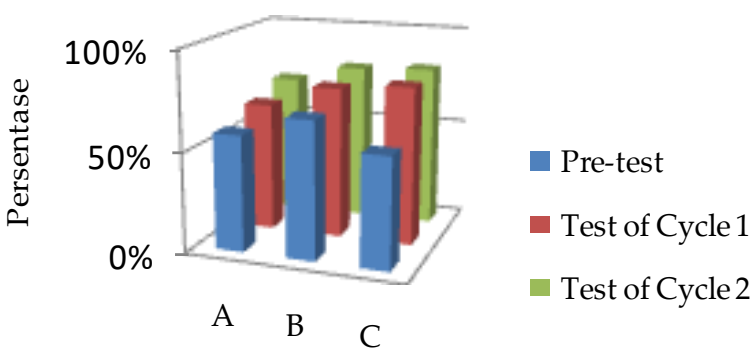

Type of Mathematical Communications

Fig 1. Increasing the percentage of student scores by aspects mathematical communication

Information:

A : Ability to provide a rationale for a statement

B : Ability to change the shape of the description into the mathematical model.

C : Ability to illustrate mathematical ideas into relevant forms of description.

A more detailed description of each aspect for each cycle is as follows:

1. Pretest, students have difficulty in terms of understanding the problem in the given problem. Most students are still confused by what the statement means. They should ask the researcher what is known and asked about the problem in question. Some students are still less thorough in solving problems. Students also have not been able to provide the right reasons for completing the answer to what was asked in the matter. Researchers provide direction and help students who have difficulty. Finally, students can work independently. The percentage of scores obtained from the pre test results is as follows: the achievement of the ability aspect gives the rationale of a statement is $58.04 \%$. The highest achievement in this aspect was achieved by grade 8 students who scored a maximum of 4 out of a maximum score of 4 and the lowest achievement was achieved by students 6,26 students and 28 students who scored 1 of the maximum score 4 . Achievement of Aspects ability to change the form of description into a mathematical model is $51,46 \%$. The highest achievement in this aspect was achieved by 12 students, 21 students and 24 students who scored 16 of the maximum score of 22 . The lowest achievement was achieved by the 6 students who scored 6 of the maximum score of 22. The achievement of the ability aspect reflected the mathematical idea into a relevant description form that is $53,32 \%$. The highest achievement in this aspect was achieved by 9 th grade students who scored 13 of the maximum score of 14 . The lowest achievement was achieved by 4 students, 14 students and 27 students who scored a maximum of 4 out of a maximum score of 14 . The ability of mathematical communication orally on pretest is still low. This can be seen from several things including: students are less able to explain the operation of the calculation, students are less able to explain mathematical solutions, and students are less able to explain the interpretation of the answers they write. 
2. Test of Cycle 1, some students still has difficulty in terms of solving the problem on rectangular and square material. Students are more careful than ever in writing the formula and using it to solve the problem. Students can also provide conclusions based on rational reasons. Researchers still provide direction and help students who have difficulty as in pretest because there are students who are still confused. Until finally students can work independently. The percentage score obtained from the Cycle 1 Test is as follows, Achievement of the ability aspect gives the rationale of a statement is $59,52 \%$. The highest achievement in this aspect was achieved by students 10 and 17 students who scored 3 of the maximum score of 3 and the lowest achievement was achieved by students 1 , student 2 , student 4 , student 11 , student 12 , student 18 , student 19 , student 20 , student 22,26 students, and 28 students who scored 1 of the maximum score 3 . Achievement of the ability aspect to change the form of description into the mathematical model is $70.00 \%$. The highest achievement in this aspect was achieved by 13 students who scored 14 of the maximum score of 15 . The lowest achievement was achieved by students 1 and 27 students who scored 5 out of a maximum score of 15 . Achievement of the ability aspect to illustrate mathematical ideas into the relevant form of descriptions is $69.64 \%$. The highest achievement in this aspect was achieved by the 23 students who scored 11 of the maximum score of 12 . The lowest achievement was achieved by students 1 who got a score of 4 out of a maximum score of 12 . There was an increase in the ability of mathematical communication orally in cycle 1 . This can be seen from several things during the learning of mathematics with the RME approach in cycle 1 is students can explain the concept into the language of mathematics, students can explain the problem into the language of mathematics, students can explain the operation of the calculation, students can explain mathematical solutions, students can explain the interpretation of answers, and students can convey ideas or opinions. Oral communication is expressed through the intensity of student involvement in small groups during the learning process.

3. Test of Cycle 2, students can do it themselves without having to ask again to the researchers. The accuracy and capability in problem solving are increasing. There is a marked improvement in students' ability to make inferences based on rational reasons. Based on the results of Test Cycle 2 percentage score obtained is as follows, Achievement aspects of the ability to provide a rationale for a statement is $72.22 \%$. The highest achievement in this aspect was achieved by 5 students, 6 students, 9 students, 10 students, 13 students, 14 students, 15 students, 18 students, 23 students, 24 students, 27 students who scored 2 of maximum score 2 and other students has been mentioned to reach the lowest point is get a score of 1 out of a maximum score of 2 . The achievement of the ability aspect to change the shape of the description into a mathematical model is $79.77 \%$. The highest achievement in this aspect was achieved by students 10, 13 students and 16 students who scored 13 of the maximum score 13 . The lowest achievement was achieved by students 2 , siawa13, students 18 , students 27 who scored 7 out of the maximum score 13 Achievement of the aspect of ability to describe the idea the mathematics into the relevant description form is $80.00 \%$. The highest achievement in this aspect was achieved by students 11 and 25 students who scored 5 out of a maximum of 5 . The lowest achievement achieved by students 2 , students 3 , students 5 , students 11 , students 13 , and students 7 who got a score of 2 of the maximum score 5 . There is an increase in the ability of mathematical communication orally on cycle 2 . This can be seen from several things during the learning of mathematics with the RME approach in cycle 2 includes: there is an increase in explaining the concepts into the language of mathematics, there is an increase in explaining the problem into the mathematical language, there is an improvement in explaining the calculation operation, there is an increase in explaining mathematical solutions, and there is an increase in conveying ideas or opinions. In addition, the intensity of student involvement in small groups and class discussions during the learning process also increases when compared to cycle 1 .

When examined again in more detail, from three aspects of mathematical communication, the greatest improvement from cycle 1 to cycle 2 is the ability aspect to provide a rationale for a statement. Based on the author's analysis through observation and theoretical studies, the increase is caused by a constructivism understanding that animates the learning steps using the RME approach. All aspects of students' mathematical communication have improved from pretest, Cycle 1 and Cycle 2 tests. So the average grade scores obtained also increased from pretest to 50.80 with moderate criteria, at Cycle 1 of 62,14 with moderate criteria and increased again to 72.96 with high criteria on the test results of Cycle Test 2. From the results of interviews with students conducted by researchers at the end of cycle II, the researchers concluded that students are very happy in the learning process using real objects. So the students more easily understand the material provided by researchers and active in learning in the classroom.

Based on the analysis obtained from the observation, test result data, and the result of the interview with the students, the researcher concludes that the learning activity of mathematics with RME approach can improve mathematical communication of class XI IPS 1 SMA Muhammadiyah 5 Yogyakarta.

\section{CONCLUSION}

Based on the results of research and discussion, it can be concluded that the Implementation of mathematics learning with Realistic Mathematics Education (RME) approach that can improve mathematical communication ability of class XI IPS 1 SMA Muhammadiyah 5 Yogyakarta is a mathematics learning that has been done in accordance with RME characteristics yaitu The use of real context, The use of mathematical models, The use of student production and construction in learning, The existence of interaction and The existence of integration. Beside that, Implementation of learning through RME approach also can improve students' mathematical communication ability on the subject using permutation and combination in problem solving in class XI IPS 1 SMA Muhammadiyah 5 Yogyakarta. This is evident from the percentage increase during the implementation of pretest, Cycle 1 and Cycle 2. The improvement of every aspect of students' mathematical communication ability from Pretest, Cycle Test 1 , and Cycle Tests 2 . 


\section{ACKNOWLEDGEMENTS}

The author would like to thank STMIK Pringsewu Lampung, Indonesia and to Dr. Fauzi, S.E., M.Kom., Akt. as chairman of the Startech Education Foundation, Rita Irviani, M.M., as chairman of STMIK Pringsewu Lampung Indonesia, LPPM of STMIK Pringsewu Lampung, and our colleagues who provided insight and expertise that greatly assisted the research.

\section{REFERENCES}

Ali et al. (2010). Effect of using problem solving method in teaching mathematics on the achievement of mathematics students. Asian Social Science, 6 (2), 66-72.

Arends \& Kilcher, A. (2010). Teaching for student learning: Becoming an accomplished teacher. New York, NY: Taylor \& Francis Group.

Freudenthal, H. (1991). Revisiting Mathematics Education.Utrech: Freudenthal Institute.

Folland, G. (2001). Communication in the Mathematical Scienses.

Fonna, M., \& Mursalin, M. (2018). Role of Self-Efficacy Toward Students' Achievement in Mathematical Multiple Representation Ability (MMRA). Jurnal Imiah Peuradeun, 6(1), 31-40.

Gravemeijer. (1994). Developing Realistic Mathematics Education. Utrecht: Kluwer Academic Publishers Press.

Hidayat, R., \& Ihsan, Z.H. (2015). The Efect of Realistic Mathematics Education (RME) on Students' Conceptual Undestanding of Linear Progamming. Creative Education, 6, 2438-2445.

Mayer, R.E. (1999). The Promise of Educational Psychology vol II: Teaching for Meaningful Learning. USA: Merill Prentice Hall.

Mursalin, M. (2011). Penerapan Strategi Pembelajaran Kreatif-Produktif Dalam Meningkatkan Pemahaman Konsep Matematika Siswa Kelas VII SMPN 2 Meurah Mulia. Jurnal Tadirs Matematika, 2(3), 1-12.

Mursalin, M. (2014). Pengembangan Buku Siswa Materi Aritmetika Sosial Berbasis Pembelajaran Model Treffinger Untuk Mendukung Kemampuan Berpikir Kreatif Siswa SMPN 19 Malang.Jurnal Pascasarjana Universitas Negeri Malang, 2(3), 1-23

Mursalin, M. (2016). Pembelajaran Geometri Bidang Datar di Sekolah Dasar Berorientasi Teori Belajar Piaget. DIKMA (Jurnal Pendidikan Matematika), 4(2), 250-258.

Palinussa, A.1., (2013). Students' Critical Mathematical Thinking and Character: Experiment for Junior High School Student Trough Realistic Mathematics Education Culture-Based. IndoMS.J.M.E, $4(1)$

Peraturan Menteri Pendidikan dan Kebudayaan Republik Indonesia Nomor 81A Tahun 2013 tentang Implementasi Kurikulum.

Peraturan Menteri Pendidikan dan Kebudayaan Republik Nomor 65 Tahun 2013 tentang Standar Proses Pendidikan Dasar dan Menengah.

Robert, K. S. (2001). “Mengapa Memilih RME/PMRI?”. Makalah. Disajikan dalam Seminar Nasional Pendidikan Matematika Realistik di USD, Yogyakarta. 14-15 November 2001.

Streefland, L. (1991). Realistic Mathematics Education in Primary School. Utrech: Freudenthal Institute.

Suherman, E dkk. (2003). Strategi Pembelajaran Matematika Kontemporer. Bandung: UPI.

Sutarto, H. (2005). Pendidikan Matematika Realistik dan Implementasinya. Banjarmasin: Tulip.

Wihatma, U. (2004). Meningkatkan Kemampuan Komunikasi Matematik Siswa SLTP melalui "Cooperative Learning" tipe "Student Team Achievement Division" (STAD): suatu penelitian tindakan kelas pada sebuah SLTP Negeri di kota Bandung. Tesis tidak diterbitkan: Pascasarjana UPI.

License information: This is an open-access article distributed under the terms of the Creative Commons Attribution License, which permits unrestricted use, distribution, and reproduction in any medium, provided the original work is properly cited. 